\title{
Large scale quantification of aquifer storage and volumes from the Peninsula and Skurweberg Formations in the southwestern Cape
}

\author{
Dylan Blake*, Andiswa Mlisa and Chris Hartnady \\ Umvoto Africa (Pty) Ltd,PO Box 61, Muizenberg, 7950, Western Cape, South Africa
}

\begin{abstract}
The Western Cape Province of South Africa is a relatively water-scarce area as a result of the Mediterranean climate experienced. Due to the increased usage of groundwater, and the requirement to know how much water is available for use, it is imperative as a $1^{\text {st }}$ step to establish an initial estimate of groundwater in storage. The storage capacity, namely, the total available storage of the different aquifers, and the storage yield of the fractured quartzitic Peninsula and Skurweberg Formation aquifers of the Table Mountain Group (TMG), are calculated with a spreadsheet and Geographic Information System (GIS) model. This model is based on the aquifer geometry and estimated values (based on measured data) for porosity and specific storage (calculated using the classic Jacob relation). The aquifer geometry is calculated from 1:50 000 and 1:250 000 geological contacts, faults and major fractures, with dips and aquifer formation thickness calculated through structural geology $1^{\text {st }}$ principles using a Digital Elevation Model (DEM). Balanced geological cross-sections constructed through the model areas provide an important check for the aquifer top and bottom surface depth values produced by the GIS model. The storage modelling undertaken here forms part of the City of Cape Town TMG Aquifer Feasibility Study and Pilot Project, with modelling focusing on the 3 main groundwater target areas at Theewaterskloof (Nuweberg), Wemmershoek and Kogelberg-Steenbras. In the storage models, the Peninsula and Skurweberg Formation aquifers have confined pore volumes ranging from approximately $29 \mathrm{bn}$. to $173 \mathrm{bn} . \mathrm{m}^{3}$ and $4 \mathrm{bn}$. to $26 \mathrm{bn}$. $\mathrm{m}^{3}$, respectively (based on using different porosity values ranging from $2.5 \%$ to $15 \%$ ). Using an average head decline of $1 \mathrm{~m}$ across the confined aquifer areas across all 3 groundwater exploration areas, and confined pore volumes based on a porosity of $5 \%, 6.9 \mathrm{Mm}^{3}$ and $1.1 \mathrm{Mm}^{3}$ of groundwater, from the Peninsula and Skurweberg Formation aquifers, respectively, is available. The aquifer storage model intentionally makes use of low, geologically reasonable values for porosity and aquifer compressibility, so as to provide minimum large-scale $1^{\text {st }}$ estimates of potential yields; however, when new data become available these initial porosity and compressibility assumptions will probably be revised upward. The storage yield approach is also very conservative, as it does not take into account the annual replenishment of the aquifer, and constitutes the yield potential during drought conditions (zero recharge) from the confined portion of the aquifer only. The yield model therefore provides a quantitative perspective on the common public and decision-maker perception that groundwater abstraction from the deep confined Peninsula Formation aquifer will significantly dewater the system, with (often unspecified) adverse ecological consequences. Even where the regionally-averaged decline in hydraulic head approaches $20 \mathrm{~m}$, the volume released by aquifer compression generally remains in the order of $0.24 \%$ of the total volume in slow circulation within the deep groundwater flow system. A vastly greater volume of groundwater is essentially non-extractable by any practical and/or economical means.
\end{abstract}

Keywords: Table Mountain Group, Peninsula Formation, Skurweberg Formation, hydrogeology, aquifer, storage modelling, storage yield

\section{Introduction}

The City of Cape Town (CoCT) initiated the Table Mountain Group (TMG) Aquifer Feasibility Study and Pilot Project in 2001, the purpose of the project being to evaluate the feasibility of augmenting the City of Cape Town's water supply using groundwater from the TMG, specifically the Peninsula and Skurweberg Formation aquifers. The project consists of 4 main phases, namely, the Inception, Preliminary, Exploratory and Pilot Wellfield Phases. The Inception and Preliminary Phases were completed in 2003 and 2005,

This paper was originally presented at the 2010 Southern African Young Water Professionals Conference, Pretoria, 19-20 January 2010.

* To whom all correspondence should be addressed.

용 +2721 788 8031; fax: +2786 524 0001; e-mail: dylan@umvoto.com respectively, with the core drilling for the Exploratory Phase completed in August 2009. The focus of the Exploratory Phase is to verify the hydrogeological findings reported on in the Preliminary Phase (City of Cape Town, 2004) through exploratory drilling and hydrogeological modelling, and the refinement and final selection of the proposed target wellfields. The storage modelling results presented here form part of the Exploratory Phase (City of Cape Town, 2008), and are based on the priority target areas identified from earlier phases and tasks in the project. The aim of calculating the storage volumes of the Peninsula and Skurweberg Formation aquifers in the southwestern Cape is to provide $1^{\text {st }}$ order, large-scale quantifiable estimates of the amount of groundwater present in storage within both aquifers, so as to assist City of Cape Town decision makers at various levels on whether to use groundwater when developing possible future bulk-scale water infrastructure schemes. 


\section{Study area}

The study area for the CoCT TMG Aquifer project is extensive, and roughly extends from Wolseley in the north to Cape Hangklip, approximately $70 \mathrm{~km}$ southwards, and from the Berg River system in the west to the Breede River system in the east, as defined by the red outlined area in Fig. 1. For the storage model study area 3 smaller model domains were delineated, namely, the Kogelberg-Steenbras, Theewaterskloof and Wemmershoek Model Domains (described in more detail below). The 3 model domains incorporate the high mountain ranges of the southwestern Cape Fold Belt (present due to the erosion-resistant nature of the arenitic units of the TMG), including the Kogelberge, Franschhoekberge, Groot Drakensteinberge, Jonkershoekberge, Stellenboschberge and Hottentots Hollandberge. There are also several wide valleys and low relief areas within the model domains (due to the erosive nature of the argillaceous Bokkeveld Group), such as the area around Theewaterskloof Dam south of Villiersdorp, and the Grabouw-Elgin area.

The study area experiences a typical Mediterranean climate with moderate temperatures and winter rainfall. The model domains include some of the highest rainfall zones in South Africa, albeit of very localised, high altitude distribution, with the end result being that many low-lying urban areas are unable to make use of the available high rainfall. These urban areas experience relative social water scarcity due to extensive development - the land area of the City of Cape Town has almost doubled since the mid-1980s, and it is projected that the population of the city will increase by almost 500000 people over the next 10 years (City of Cape Town, 2009). Average mean annual precipitation (MAP) exceeds $1500 \mathrm{~mm}$ around the Drakensteinberge between Stellenbosch and Franschhoek, and in general the regions of high rainfall coincide with topographically-elevated mountain chains, mainly underlain by the erosion-resistant, but highly fractured TMG rocks.

\section{Stratigraphy and hydrostratigraphy}

The stratigraphy and hydrostratigraphy of the study domains is summarised in Table 1 (derived from Gresse and Theron (1992), Theron et al. (1992) and the Department of Water Affairs (DWAF, 2000a; b).

The model domain geology is dominated by the Palaeozoic sedimentary rocks of the Cape Supergroup, which overlie the basement Malmesbury Group and Cape Granite Suite. The 2 formations of interest are the fractured, light greyish-white coloured, thickly-bedded quartzitic Peninsula and Skurweberg Formations of the TMG, which are the topographically dominant units that form the high mountain ranges. Both formations are also hydrogeologically important as a result of their wide areal extent in the areas of maximum precipitation and recharge potential, as well as having the greatest subsurface volume of permeable fractured rock (being the thickest fractured quartzitic units in the TMG and Cape Supergroup as a whole). The Peninsula Formation is overlain by the glaciogenic Pakhuis Formation, argillaceous Cedarberg Formation and fine sandstone/siltstone dominated Goudini Formation (which form the combined Winterhoek Mega-aquitard), whereas the Skurweberg Formation is overlain by the Rietvlei Formation of the TMG and the Bokkeveld Group (which forms part of the Gydo Mega-aquitard) (see City of Cape Town (2004) and Thamm and Johnson (2006) for more geological detail).

The Cape Supergroup and basement rocks underwent an episode of compressional deformation from the early Permian to Triassic known as the Cape Orogenic Cycle, which led to the

\begin{tabular}{|c|c|c|c|c|c|c|c|}
\hline \multicolumn{8}{|c|}{$\begin{array}{c}\text { Table } 1 \\
\text { Stratigraphy and hydrostratigraphy of the TMG storage model domains }\end{array}$} \\
\hline \multicolumn{5}{|c|}{ Stratigraphy } & \multicolumn{3}{|c|}{ Hydrostratigraphy } \\
\hline $\begin{array}{l}\text { Age range } \\
\text { (Ma) }\end{array}$ & Supergroup & Group & Formation & Description & $\begin{array}{l}\text { Super- } \\
\text { unit }\end{array}$ & Unit & Subunit \\
\hline $2-0$ & & $\begin{array}{l}\text { Sandveld / } \\
\text { Bredasdorp }\end{array}$ & (Various) & Alluvium & & Quaternary Aquifer & \\
\hline 136 & & False Bay Suite & & Dolerite dykes & & & \\
\hline \multicolumn{8}{|c|}{$\begin{array}{l}\sim \sim \sim \sim \text { Major unconformity } \sim \sim \sim \sim \sim \\
\end{array}$} \\
\hline \multirow{3}{*}{$354-417$} & \multirow{9}{*}{ Cape } & Bokkeveld & (Various) & $\begin{array}{l}\text { Shales and minor } \\
\text { sandstone }\end{array}$ & & Gydo Mega-aquitard & \\
\hline & & \multirow{8}{*}{ Table Mountain } & \multirow[b]{2}{*}{ Rietvlei } & \multirow{2}{*}{$\begin{array}{l}\text { Feldspathic sand- } \\
\text { stone; minor shale }\end{array}$} & \multirow{8}{*}{  } & \multirow{3}{*}{ Nardouw Aquifer } & Rietvlei Subaquifer \\
\hline & & & & & & & $\begin{array}{l}\text { Verlorenvalley } \\
\text { Mini-aquitard }\end{array}$ \\
\hline \multirow{6}{*}{$417-443$} & & & Skurweberg & $\begin{array}{l}\text { Thickly bedded } \\
\text { quartzite }\end{array}$ & & & $\begin{array}{l}\text { Skurweberg } \\
\text { Subaquifer }\end{array}$ \\
\hline & & & Goudini & $\begin{array}{l}\text { Reddish brown } \\
\text { quartzitic sandstone }\end{array}$ & & \multirow{3}{*}{$\begin{array}{l}\text { Winterhoek } \\
\text { Mega-aquitard }\end{array}$} & Goudini Meso-aquitard \\
\hline & & & Cedarberg & $\begin{array}{l}\text { Dark grey shale and } \\
\text { siltstone }\end{array}$ & & & $\begin{array}{l}\text { Cedarberg } \\
\text { Meso-aquitard }\end{array}$ \\
\hline & & & Pakhuis & $\begin{array}{l}\text { Diamictite and } \\
\text { quartz sandstone }\end{array}$ & & & Pakhuis Mini-aquitard \\
\hline & & & \multirow{2}{*}{ Peninsula } & \multirow{2}{*}{$\begin{array}{l}\text { Thickly bedded } \\
\text { quartzite }\end{array}$} & & \multirow{2}{*}{ Peninsula Aquifer } & Platteklip Subaquifer \\
\hline & & & & & & & Leeukop Subaquifer \\
\hline \multicolumn{8}{|c|}{$\begin{array}{l}\sim \sim \sim \text { Major unconformity } \sim \sim \sim \sim \\
\end{array}$} \\
\hline $495-545$ & \multirow{2}{*}{ (Saldanian) } & $\begin{array}{l}\text { Cape Granite } \\
\text { Suite }\end{array}$ & & Granite & & \multirow{2}{*}{ Basement Aquicludes } & \\
\hline $545->750$ & & Malmesbury & & Metasediments & & & \\
\hline
\end{tabular}


Figure 1

TMG storage model domains (red outlines), with local geology superimposed on a $20 \mathrm{~m}$ digital elevation model (DEM). Balanced structural lines through priority target sites identified in City of Cape Town (2004) in yellow. Top right Google Earth image inset shows study area relative to False Bay, the Cape Peninsula and Cape Flats in the CoCT.



development of large northward-directed asymmetric anticlines (as well as large faults and fractures) within the competent Peninsula Formation, and the formation of the scenic Cape Fold Belt in the southwestern Cape (Newton et al., 2006). Post-Cape rocks and sediments include the $\sim 136$ Ma dolerite dyke swarm of the False Bay Suite, which intrudes the underlying basement and Cape Supergroup in False Bay and the Kogelberge, and Tertiary to Quaternary aged sediment. The sedimentary units are composed of the Bredasdorp Group (coastal sediments east of Cape Hangklip), Sandveld Group (coastal sediments west of Cape Hangklip) (Roberts et al., 2006), and unclassified fluvial and floodplain sediment.

\section{Model domains}

Storage model development was undertaken for the priority target site areas, as selected for the Exploratory Phase (City of Cape Town, 2004), namely, Wemmershoek (Site W7), Theewaterskloof (Sites T4, B1) and Kogelberg-Steenbras (Site H8). The delineation of the separate model domains mainly followed geological/hydrogeological boundaries, such as major faults, lithological contacts and, in case of the subdivision in the Kogelberg-Steenbras area, dykes.

\section{Kogelberg-Steenbras Model Domain}

The Kogelberg-Steenbras Model Domain (KGB) forms the most southern part of the study area and comprises the TMG aquifers between Grabouw and Pringle Bay. The northwestern boundary of the model domain follows the contact between the basement and the Peninsula Formation. The western and southern boundary is marked by False Bay; the southeastern boundary follows the TMG outcrop in the Bot River valley, while the Groenlandberg Fault represents the northern boundary of the model domain. Due to the complex geological structure in the area and the presence of dykes from the False Bay Suite, the model domain was divided into smaller units that can be considered as separate aquifer compartments. These are KS1 to KS3 northwest of the Steenbras-Brandvlei Megafault (SBM) and KS4 to KS6 southeast of the SBM in Fig. 1, which are divided by crosscutting dykes. The southeastern boundary of the subdivisions is formed by the southern extension of the Riviersonderend Fault, with the remainder of the model domain being named KS in Fig. 1. These subdivisions are based on the assumption that both dykes and mega faults are hydraulic barriers to groundwater flow. 


\section{Theewaterskloof Model Domain}

The Theewaterskloof Model Domain (THK) is the biggest of the selected domains (delineated as T in Fig. 1), stretching from Villiersdorp in the northeast to Franschhoek in the north, Stellenbosch and Somerset West in the west and Bot River in the south. It contains the Theewaterskloof Dam in the centre and the high mountains of the Hottentots-Holland mountain range in the west. The model domain is bounded by major faults in the north and the south, while the western boundary is delineated along the contact between the basement and the Peninsula Formation.

\section{Wemmershoek Model Domain}

The Wemmershoek Model Domain (WEM) is the smallest of the 3 model domains and consists of the Wemmershoek Dam and surrounding mountains (delineated as W in Fig. 1). It is bounded by the Klein Drakenstein Fault in the north, and a splay fault connecting the Klein Drakenstein and La Motte Fault in the south. The western boundary is formed by the contact between the basement and the Peninsula Formation.

\section{Methodology}

\section{Storage model}

The storage model aims to develop a relatively accurate 3-D surface of the base and top of the Peninsula and Skurweberg Formation aquifers, and to obtain the rock volume and model the amount of groundwater in storage as well as the amount of groundwater available for sustainable abstraction from both aquifers. Storage modelling was undertaken for both aquifers in the various model domains using a combination of in-house Microsoft Excel spreadsheet models and Geographic Information System (GIS) applications in TNTmips, following the procedure used in the Clanwilliam Dam Raising study (DWAF, 2006). The spreadsheet models require 3-D input (X, $\mathrm{Y}$ and $\mathrm{Z}$ coordinates) of geological contacts, derived from georeferenced satellite imagery and a $20 \mathrm{~m}$ x $20 \mathrm{~m}$ DEM (which was developed for the Berg Water Management Area water availability assessment study (DWAF, 2008)).

The X-Y-Z data is first used to calculate orientations of particular geological contacts at specified intervals along the surface trace in an initial spreadsheet model, using $1^{\text {st }}$ order geological principles, Euclidean geometry and trigonometry. These contacts enclose a total area of $1686 \mathrm{~km}^{2}$ and $994 \mathrm{~km}^{2}$ for the Peninsula and Skurweberg Formation storage basins, respectively. After GIS inspection and consistency checks against existing map data, a $2^{\text {nd }}$ spreadsheet model is used to calculate depths to, and elevations of, the top and base boundaries of the aquifer units at all points along the mapped contacts using trigonometric relations. True thickness information, preferably derived from remote sensing measurements between the base and top boundaries along short section lines of well-known strike and dip value, is also used in these checks. For the model domains an average true thickness of $700 \mathrm{~m}$ (KGB) and $1100 \mathrm{~m}$ (THK and WEM) was used for the Peninsula Formation, while an average true thickness of $200 \mathrm{~m}$ (KGB) and $300 \mathrm{~m}$ (THK) was used for the Skurweberg Formation (the Skurweberg Formation is unconfined in WEM).

The X-Y-Z data for the aquifer base and top, augmented by additional, in-fill elevation data derived from fault geometry and borehole data, is imported into a GIS model. The data are then fitted to a referenced surface, from which a raster grid model at the same grid interval as the DEM is prepared for the top and bottom boundaries of the aquifer (the volumes are hence only as accurate as the DEM grid interval). The subsurface volume of the aquifer is then calculated by sequential subtraction of the aquifer base from surface topography, and then the aquifer top from surface topography, to obtain the solid volumes above each, and finally subtraction of the top value from the base value. Seven balanced structural geological cross-sections (whose locality and design are shown in Figs. 1 and 2, respectively) were also constructed through the model areas in order to provide an important check for the aquifer top and bottom surface depth values produced by the GIS model. The balanced cross-sections, and model as a whole, are based on the assumption that in the CoCT TMG Aquifer study area, the aquifer units have undergone flexural slip (or bedding parallel) folding, implying that the orthogonal thickness of the units remains constant about the fold hinges and across the limbs of the folds.

The unconfined and confined portions of the aquifer are distinguished and delineated according to the surface expression of the overlying units. The total area, average apparent thickness and total rock volume are obtained for both the confined and unconfined portions of the aquifer and summed to obtain the totals. Porosity data are then used to calculate the total pore volume present. For this model and study, porosity is defined as the space formed by continuous open fractures of variable size that are effective in contributing to fluid flow. Porosity estimates for a $325 \mathrm{~m}$ to $800 \mathrm{~m}$ deep section of the Peninsula Formation aquifer in the Blikhuis Experimental Deep Drilling (BEDD) Project borehole BH2, between Citrusdal and Clanwilliam, have been undertaken from downhole resistivity and density logging (Hartnady and Curot, 2002). Porosity values range from 4.8 to $6 \%$, for the 'matrix' or relatively unfractured borehole sections, to 16 to $28 \%$ for highly fractured zones. Porosity analysis of TMG sandstone core samples (using the volumetric method) by Xu et al. (2009) have indicated a porosity range of 1 to $3.6 \%$, with an average porosity of $2.5 \%$ (although it is not mentioned which formation the samples were taken from). Porosity density logging from the Rietfontein deep borehole has indicated average porosities of $5.7 \%$ for clean sandstones and $16.4 \%$ for fractured sandstones, although the data are from the Piekenierskloof Formation of the TMG (Xu et al., 2009). Porosity values still require future experimental confirmation from the present study area, although current geophysical data analysis (density and neutron ratio porosity) from 6 core boreholes indicates average porosities between 6 and $8 \%$ for the Peninsula Formation. Porosity values of $2.5 \%$ (Xu et al., 2009), $5 \%$ (low-end values from Hartnady and Curot, 2002), 8\% (high-end unpublished data from boreholes in the study area) and $15 \%$ (close to high-end porosity values from Hartnady and Curot (2002) and Xu et al. (2009)) were used to calculate the total pore volume, as tabulated in Table 2.

\section{Storage yield model}

A storage yield model was developed to evaluate the potential yield of the aquifers with respect to hydraulic head decline and acceptable environmental impacts. The model uses the results from the storage model to calculate the potential yield of the Peninsula and Skurweberg Formation aquifers in the model domains. Since large-scale groundwater abstraction is proposed 


\begin{tabular}{|c|c|c|c|c|c|c|c|}
\hline \multicolumn{8}{|c|}{$\begin{array}{c}\text { Table } 2 \\
\begin{array}{c}\text { Rock volume vs. pore volume for the Peninsula and Skurweberg Formation aquifers, } \\
\text { given porosity values of } 2.5 \%, 5 \%, 8 \% \text { and } 15 \%\end{array}\end{array}$} \\
\hline \multirow{2}{*}{\multicolumn{2}{|c|}{ Aquifer }} & \multirow{3}{*}{\begin{tabular}{l|}
$\begin{array}{c}\text { Area } \\
\left(\mathbf{k m}^{2}\right)\end{array}$ \\
474.53 \\
\end{tabular}} & \multirow{3}{*}{$\begin{array}{c}\begin{array}{c}\text { Rock volume } \\
\left(\mathbf{M m}^{3}\right)\end{array} \\
297314\end{array}$} & \multicolumn{4}{|c|}{ Pore Volume $\left(\mathrm{Mm}^{3}\right)$} \\
\hline & & & & $2.5 \%$ & $5 \%$ & $8 \%$ & $15 \%$ \\
\hline \multirow{3}{*}{$\begin{array}{l}\text { Peninsula } \\
\text { Formation }\end{array}$} & Unconfined portion & & & 7433 & 14866 & 23785 & 44597 \\
\hline & Confined portion & 1206.42 & 1154373 & 28859 & 57719 & 92350 & 173156 \\
\hline & Whole aquifer & 1680.95 & 1451687 & 36292 & 72584 & 116135 & 217753 \\
\hline \multirow{3}{*}{$\begin{array}{l}\text { Skurweberg } \\
\text { Formation }\end{array}$} & Unconfined portion & 373.74 & 89348 & 2234 & 4467 & 7148 & 13402 \\
\hline & Confined portion & 610.95 & 174870 & 4372 & 8744 & 13990 & 26231 \\
\hline & Whole aquifer & 984.69 & 264218 & 6605 & 13211 & 21137 & 39633 \\
\hline
\end{tabular}

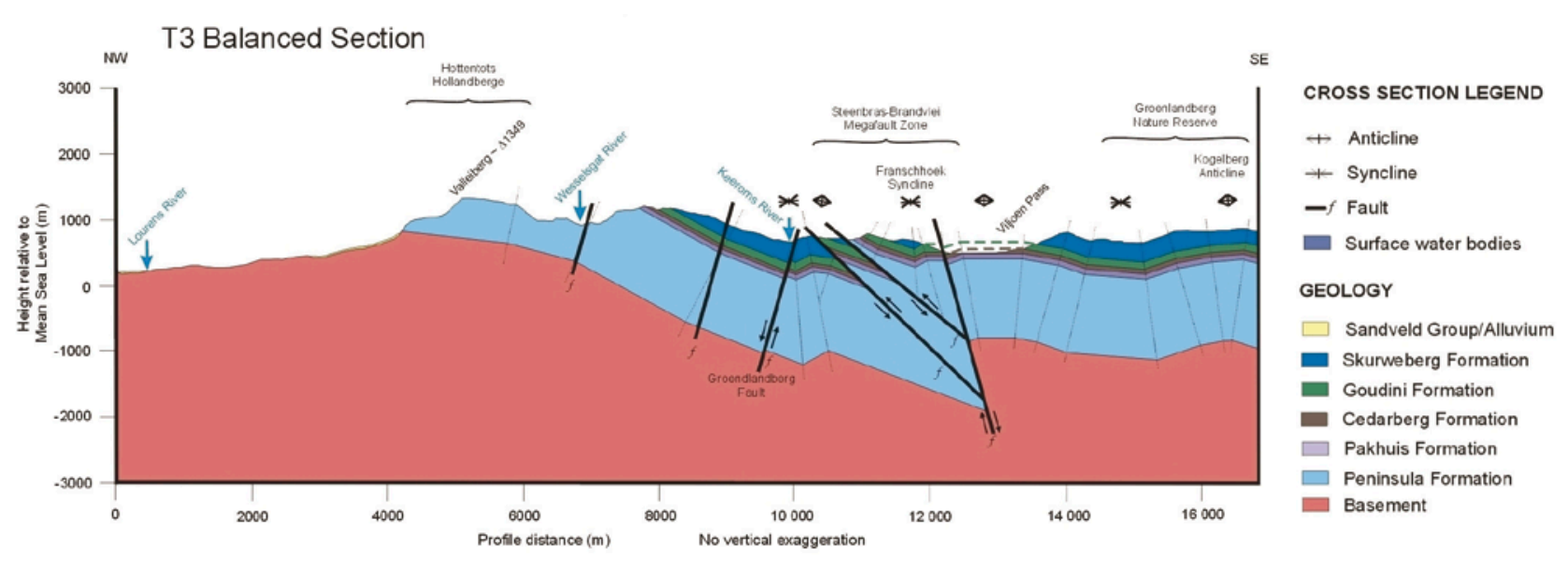

Figure 2

Balanced structural cross-section constructed through $T 3$ in the Theewaterskloof Model Domain

for the confined portion of the aquifer only, the regional hydraulic head decline due to abstraction depends upon the storativity of the aquifer.

The volume of water (in $\mathrm{m}^{3}$ ) that can be released from the aquifer per unit area $\left(\right.$ in $\mathrm{m}^{2}$ ) for a unit decline of head (in $\mathrm{m}$ ) is termed storativity. Sharp (1999) states that in a confined aquifer system, storativity is essentially the specific storage (the volume of water released by the aquifer's skeletal matrix per unit decline of head) multiplied by the aquifer thickness, whereas in an unconfined aquifer system, storativity is essentially equal to the specific yield or porosity. Specific storage $\left(\mathrm{S}_{\mathrm{s}}\right)$ is calculated by using the classic Jacob relation, $S_{s}=r_{w} g\left(b_{p}+n b_{w}\right)$, where: $r_{w}$ is the mass density of water $\left(\mathrm{kg} \cdot \mathrm{m}^{-3}\right), g$ is the gravitational acceleration $\left(\mathrm{m} . \mathrm{s}^{-2}\right), b_{p}$ is the 'skeletal compressibility' of the fracture-porous aquifer matrix $\left(\mathrm{m}^{2} \cdot \mathrm{N}^{-1}\right.$ or $\left.\mathrm{Pa}^{-1}\right), b_{w}$ is the compressibility of water, and $n$ is the porosity, expressed as a dimensionless ratio.

A porosity of 5\% (low-end Peninsula Formation porosity values from Hartnady and Curot, 2002) was used in association with the vertical compressibility of fractured rocks $\left(3.3 \times 10^{-10} \mathrm{~Pa}^{-1}\right.$ and $6.9 \times 10^{-10} \mathrm{~Pa}^{-1}$; Domenico and Schwartz, 1990) to delineate a range of specific storage values between $3 \times 10^{-6}$ and $7 \times 10^{-6} \mathrm{~m}^{-1}$, with an accepted value of $6 \times 10^{-6} \mathrm{~m}^{-1}$ being used to calculate the storativity of the Peninsula and Skurweberg Formation aquifers in the model domain areas. Inflows into and outflows from the aquifer are ignored for the storage and storage yield models (although they have been taken into account in the development of an associated water balance model for both aquifers (City of Cape Town, 2008)).

\section{Storage model results}

\section{Peninsula Formation aquifer}

The areas where the Peninsula Formation aquifer exists in an unconfined or confined state are considered in the storage model, and these are coloured in the study area storage model figures, as shown in Fig. 3. The colour palette illustrates the elevation of the aquifer top and bottom relative to mean sea level. Blues and purples indicate where the Peninsula Formation aquifer is at its deepest while reds indicate where it outcrops at surface or has been eroded away above the basement. The regions where the Peninsula Formation is at its deepest include the Villiersdorp Syncline in the vicinity of Grabouw and Theewaterskloof Dam, whereas surface outcrops occur along the mountain ranges in the Franschhoek, Stellenbosch and Kogelberg areas.

The total solid material volume (rock volume) of the Peninsula Formation aquifer is $1451 \mathrm{bn} . \mathrm{m}^{3}$. The total confined rock volume is $1154 \mathrm{bn} . \mathrm{m}^{3}$. The total (and confined) modelled rock volume and the calculated pore volume (rock volume $\mathrm{x}$ porosity, used for both confined and unconfined portions), using a range of porosities, is summarised in Table 2. The total confined pore volume of the Peninsula Formation aquifer hence ranges from approximately $29 \mathrm{bn} . \mathrm{m}^{3}$ (2.5\% porosity) to $173 \mathrm{bn} . \mathrm{m}^{3}$ (15\% porosity).

\section{Skurweberg Formation aquifer}

As with the Peninsula Formation aquifer model, only the areas where the Skurweberg Formation aquifer exists in a 
(a)



(b)

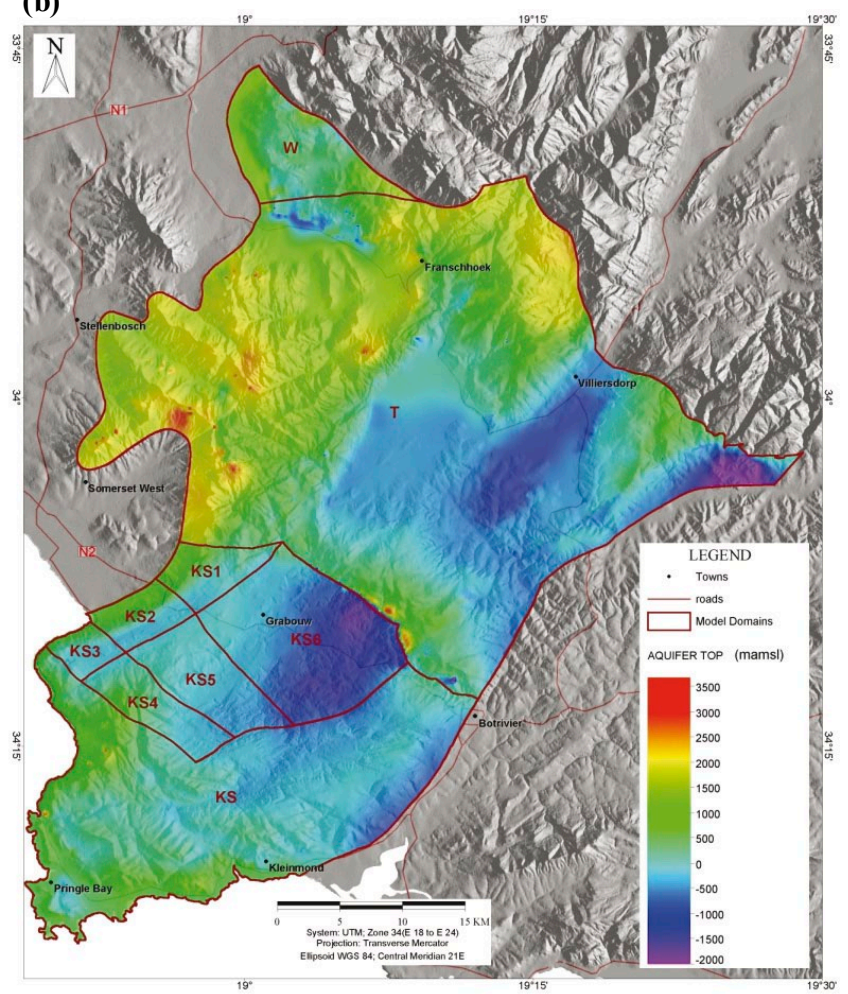

Figure 3

Peninsula Formation aquifer bottom (a) and top (b) modelled surfaces

(a)

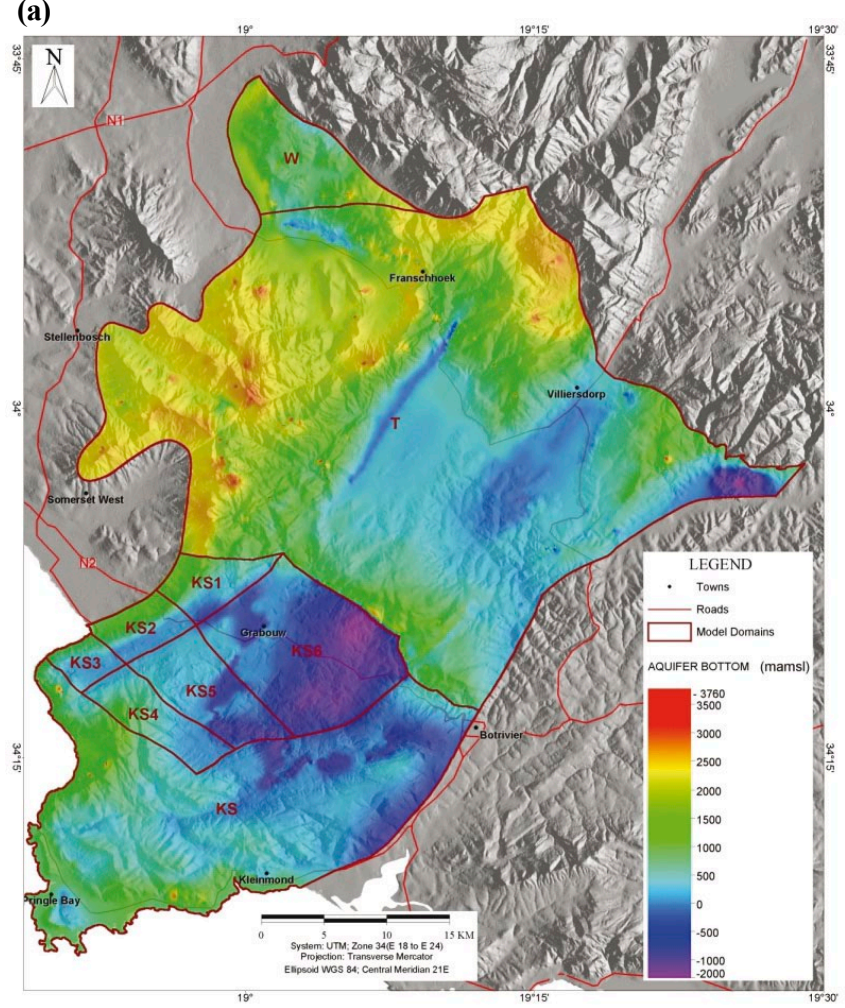

(b)

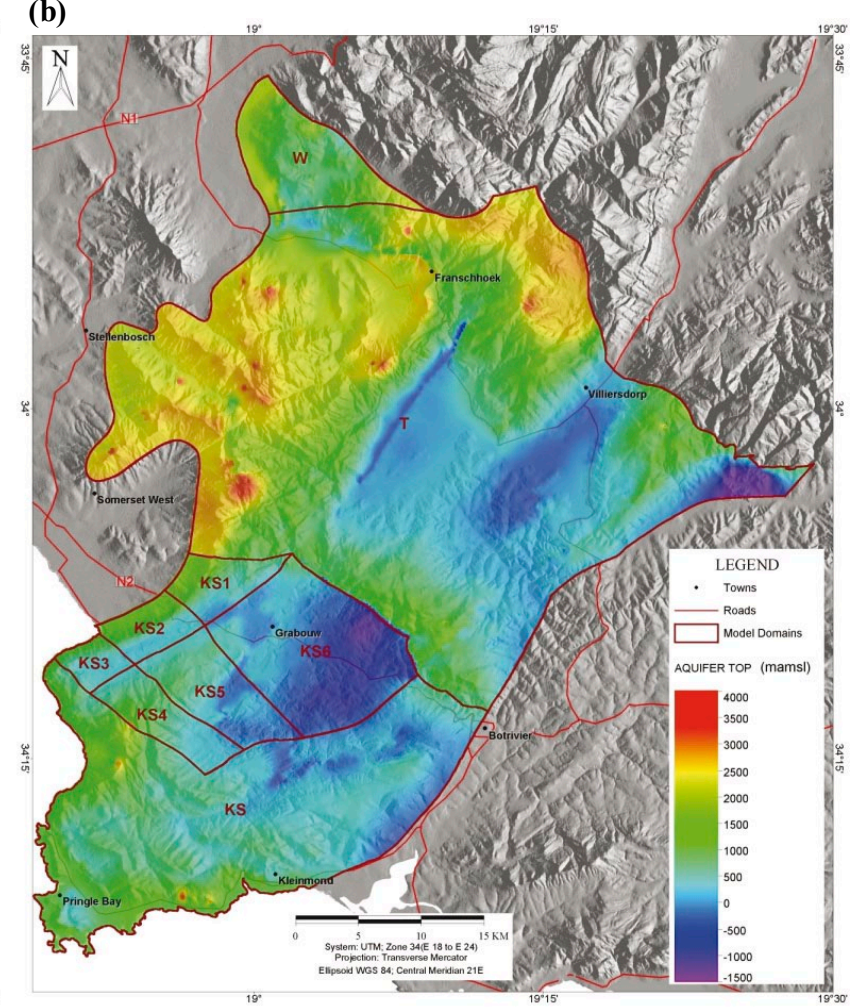

Figure 4

Skurweberg Formation aquifer bottom (a) and top (b) modelled surfaces

confined or unconfined stated are considered in the storage model, and these are coloured in the study area storage model figures, as shown in Fig. 4. The same colour palette system has been applied as described above, hence blues and purples indicate where the Skurweberg Formation aquifer is at its deepest while yellows and reds indicate where it outcrops at surface or has been eroded away above underlying units. As with the Peninsula Formation, the regions where the Skurweberg Formation is at its deepest include the Villiersdorp Syncline in the vicinity of Grabouw and Theewaterskloof 
Dam. The Skurweberg Formation outcrops mainly within the Kogelberg area, as well as in the vicinity of Grabouw north of the Groenlandberg Fault and either side of the Villiersdorp Syncline near Villiersdorp.

The total solid material volume (rock volume) of the Skurweberg Formation aquifer is $264 \mathrm{bn} . \mathrm{m}^{3}$. The total confined rock volume is $175 \mathrm{bn} . \mathrm{m}^{3}$. The total (and confined) modelled rock volume and the calculated pore volume (rock volume $\mathrm{x}$ porosity, used for both confined and unconfined portions), using a range of porosities, is summarised in Table 2. The total confined pore volume of the Skurweberg Formation aquifer ranges from approximately $4 \mathrm{bn} . \mathrm{m}^{3}$ ( $2.5 \%$ porosity) to 26 bn. $\mathrm{m}^{3}$ (15\% porosity).

\section{Storage yield results}

Using confined pore volumes based on 5\% porosity, the volumes of water elastically released from confined storage in the Peninsula $\left(57.7 \mathrm{bn} . \mathrm{m}^{3}\right)$ and Skurweberg $\left(8.7 \mathrm{bn} . \mathrm{m}^{3}\right)$ Formation aquifers due to unit head or pressure decline, causing mainly porosity reduction (aquifer compression), are just a small fraction in comparison to the total volume of groundwater in storage. For the assumption of $5 \%$ porosity with a specific storage of $6 \times 10^{-6} \mathrm{~m}^{-1}$, the total volume of subsurface water released from a $1 \mathrm{~m}$ unit head decline in the confined Peninsula and Skurweberg Formation aquifers is 6.9 and $1.1 \mathrm{~m} . \mathrm{m}^{3}$ respectively, only $0.01 \%$ of the total water in storage (Tables 3 and 4). The volume of stored water released increases as the head decline increases, but still remains below $0.5 \%$ even with a $20 \mathrm{~m}$ unit head decline.

\section{Discussion and conclusion}

There are both advantages and limitations to using a digital GIS storage model. Advantages include the fact that the model is physically correct, at the scale limitations used, in terms of obtaining the rock volume; it is possible to obtain a visually descriptive spatial overview of the aquifer geometry; and the apparent thickness of the aquifer can be more accurately determined than in earlier estimations where only broad or representative geology data was applied. Limitations of the model include the fact that it is only as accurate as the scale of the input data, however the use of $20 \mathrm{~m}$ x $20 \mathrm{~m}$ DEM and the 1:50 000 and 1:250 000 geological maps imply that the results are reliable for the scale of the model domains. Also, the exact depth of contacts cannot be accurately determined at fault zones, but they can be reasonably estimated with further ground-truth information being obtained from drilling. The aquifer storage model intentionally makes use of low, geologically reasonable values for porosity and aquifer compressibility, so as to provide minimum estimates of the amount of water in storage and subsequently the potential yield. It is anticipated

\begin{tabular}{|c|c|c|c|c|c|c|c|c|}
\hline & Potential & $\begin{array}{l}\text { eld of th } \\
\text { the mo }\end{array}$ & $\begin{array}{l}\text { fine } \\
\text { mai }\end{array}$ & $\begin{array}{l}\text { Table } \\
\text { tions } \\
\text { ased }\end{array}$ & $\begin{array}{l}\text { e Penir } \\
\text { e stora }\end{array}$ & $\begin{array}{l}\text { Form } \\
\text { eld } \mathrm{m}\end{array}$ & aquif & \\
\hline Model & Storativity & & & & ume pe & decli & & \\
\hline Domain & & volume & & & & & & \\
\hline & & & $\mathrm{Mm}^{3}$ & $\%$ & $\mathrm{Mm}^{3}$ & $\%$ & $\mathrm{Mm}^{3}$ & $\%$ \\
\hline KS & $4.23 \mathrm{E}-03$ & 10189 & 1.22 & 0.01 & 6.11 & 0.06 & 24.45 & 0.24 \\
\hline KS1 & $4.23 \mathrm{E}-03$ & 695 & 0.08 & 0.01 & 0.42 & 0.06 & 1.67 & 0.24 \\
\hline KS2 & $4.20 \mathrm{E}-03$ & 456 & 0.05 & 0.01 & 0.27 & 0.06 & 1.09 & 0.24 \\
\hline KS3 & $4.23 \mathrm{E}-03$ & 402 & 0.05 & 0.01 & 0.24 & 0.06 & 0.96 & 0.24 \\
\hline KS4 & $4.31 \mathrm{E}-03$ & 1327 & 0.16 & 0.01 & 0.8 & 0.06 & 3.19 & 0.24 \\
\hline KS5 & $4.20 \mathrm{E}-03$ & 1954 & 0.23 & 0.01 & 1.17 & 0.06 & 4.69 & 0.24 \\
\hline KS6 & $4.22 \mathrm{E}-03$ & 4695 & 0.56 & 0.01 & 2.82 & 0.06 & 11.27 & 0.24 \\
\hline THK & $7.06 \mathrm{E}-03$ & 36414 & 4.37 & 0.01 & 21.85 & 0.06 & 87.39 & 0.24 \\
\hline WEM & $6.82 \mathrm{E}-03$ & 1586 & 0.19 & 0.01 & 0.95 & 0.06 & 3.81 & 0.24 \\
\hline Total & $5.74 \mathrm{E}-03$ & 57719 & 6.93 & 0.01 & 34.63 & 0.06 & 138.52 & 0.24 \\
\hline
\end{tabular}

\begin{tabular}{|c|c|c|c|c|c|c|c|c|}
\hline & Potential y & $\begin{array}{l}\text { eld of the } \\
\text { r the mo }\end{array}$ & $\begin{array}{l}\text { fined } \\
\text { domai }\end{array}$ & $\begin{array}{l}\text { Table } \\
\text { ons o } \\
\text { ased }\end{array}$ & $\begin{array}{l}\text { Skurw } \\
\text { stora }\end{array}$ & $\begin{array}{l}\text { Forn } \\
\text { eld } \mathrm{m}\end{array}$ & aqu & \\
\hline \begin{tabular}{|l|} 
Model \\
\end{tabular} & Storativity & Pore & & & me pe & declin & & \\
\hline Domain & & volume & & & & & & \\
\hline & & & $\mathrm{Mm}^{3}$ & $\%$ & $\mathbf{M m}^{3}$ & $\%$ & $\mathrm{Mm}^{3}$ & $\%$ \\
\hline KS & $1.55 \mathrm{E}-03$ & 750 & 0.09 & 0.01 & 0.07 & 0.06 & 0.30 & 0.24 \\
\hline KS1 & $1.43 \mathrm{E}-03$ & 124 & 0.01 & 0.01 & 0.07 & 0.06 & 0.28 & 0.24 \\
\hline KS2 & $1.29 \mathrm{E}-03$ & 117 & 0.01 & 0.01 & 0.05 & 0.06 & 0.18 & 0.24 \\
\hline KS3 & $1.39 \mathrm{E}-03$ & 77 & 0.01 & 0.01 & 0.06 & 0.06 & 0.23 & 0.24 \\
\hline KS4 & $1.67 \mathrm{E}-03$ & 98 & 0.01 & 0.01 & 0.27 & 0.06 & 1.10 & 0.24 \\
\hline KS5 & $1.43 \mathrm{E}-03$ & 458 & 0.05 & 0.01 & 0.95 & 0.06 & 3.79 & 0.24 \\
\hline KS6 & $1.49 \mathrm{E}-03$ & 1579 & 0.19 & 0.01 & 0.45 & 0.06 & 1.80 & 0.24 \\
\hline THK & $1.90 \mathrm{E}-03$ & 5541 & 0.66 & 0.01 & 3.32 & 0.06 & 13.30 & 0.24 \\
\hline WEM & & Jo confine & rtion $\mathrm{o}$ & weber & ation a & in this & 1 Dome & \\
\hline Total & $1.72 \mathrm{E}-03$ & 8744 & 1.05 & 0.01 & 5.25 & 0.06 & 20.98 & 0.24 \\
\hline
\end{tabular}


that these initial porosity and compressibility assumptions will be revised upwards, as new porosity data from the Peninsula and Skurweberg Formations in the study area are analysed, and formation specific aquifer compressibility determined (e.g. the skeletal compressibility of the Peninsula Formation in the Hermanus area (Hartnady et al., 2008)).

The storage yield results serve to put into quantitative perspective the common public and decision-making (whether it be local or regional government) perception that groundwater abstraction from the deep confined aquifers, and the Peninsula Formation aquifer specifically, will somehow significantly dewater the system, with (often unspecified) adverse ecological consequences. Even where the regionally averaged decline in hydraulic head approaches $20 \mathrm{~m}$, the volume released by aquifer compression generally remains only $0.24 \%$ of the total volume in slow circulation within the deep groundwater flow system. A vastly greater volume of groundwater is essentially non-extractable by any practical and/or economical means. The storage and storage yield models are also very conservative in that they do not take into account the annual replenishment of the aquifer, and they therefore constitute the yield potential during drought conditions (i.e. zero recharge).

How much water actually abstracted is an aquifer management issue, and would need to take into consideration the impacts of abstraction, social factors, economic advantages, advantages (environmental and yield) arising from conjunctive use, and water saving arising from conjunctive use. The results from the exploratory drilling, such as formation thickness and dips, and aquifer porosity will be used to refine the storage model and storage yield model in order to assist in future wellfield siting and aquifer management. A thorough understanding of the geology and hence aquifer geometry of the model area has shown to be essential for a large-scale, $1^{\text {st }}$ order quantification of groundwater availability from the Peninsula and Skurweberg Formations for the City of Cape Town.

\section{References}

CITY OF CAPE TOWN (2004) Hydrogeological Report. Prepared by the TMG Aquifer Alliance as part of the Preliminary Phase of the Table Mountain Group Aquifer Feasibility Study and Pilot Project.

CITY OF CAPE TOWN (2008) Water Balance Model Report. Prepared by the TMG Aquifer Alliance as part of the Exploratory Phase of the Table Mountain Group Aquifer Feasibility Study and Pilot Project.

CITY OF CAPE TOWN (2009) Cape Town Spatial Development Framework ( $1^{\text {st }}$ Draft). Spatial Planning and Urban Design Department, City of Cape Town.

DWAF (DEPARTMENT OF WATER AFFAIRS AND FORESTRY, SOUTH AFRICA) (2000a) 1:500 000 General Hydrogeological Map Cape Town 3317. Department of Water Affairs and Forestry, Pretoria, South Africa.
DWAF (DEPARTMENT OF WATER AFFAIRS AND FORESTRY, SOUTH AFRICA) (2000b) Reconnaissance investigation into the development and utilisation of the Table Mountain Group artesian groundwater, using the E10 Catchment as a pilot study area: Final Report. Umvoto Africa and SRK Consulting, Cape Town. Department of Water Affairs and Forestry, Pretoria, South Africa.

DWAF (DEPARTMENT OF WATER AFFAIRS AND FORESTRY, SOUTH AFRICA) (2006) Groundwater Resource Evaluation Report. Prepared by Umvoto Africa, as part of the Feasibility Study for the raising of Clanwilliam Dam in the Western Cape. Department of Water Affairs and Forestry, Pretoria, South Africa.

DWAF (DEPARTMENT OF WATER AFFAIRS AND FORESTRY, SOUTH AFRICA) (2008) The Assessment of Water Availability in the Berg Catchment (WMA 19) by Means of Water Resource Related Models: Groundwater Model Report Volume 3 Conceptual Model Report. Prepared by Umvoto Africa (Pty) Ltd. in association with Ninham Shand (Pty) Ltd. on behalf of the Directorate: National Water Resource Planning. DWAF Report No. P WMA 19/000/00/0408. Department of Water Affairs and Forestry, Pretoria, South Africa.

DOMENICO PA and SCHWARTZ FW (1990) Physical and Chemical Hydrogeology. John Wiley \& Sons.

GRESSE PG and THERON JN (1992) The Geology of the Worcester area: Explanation of Sheet 3319, scale 1:250 000. Geological Survey of South Africa, Department of Mineral and Energy Affairs, Pretoria.

HARTNADY CJH and CUROT S (2002) In situ borehole laboratory for Table Mountain Group fractured rock hydrotectonics research. Blikhuis Experimental Deep Drilling (BEDD) Project, Table Mountain Group (TMG), Western Cape Province, South Africa.

HARTNADY CJH, MLISA A and NQUMASHE T (2008) Development and Applications of Global Navigational Satellite Systems (GNSS) Methodology for Groundwater Resource Assessment (Inception Report). WRC Project No. K5/1851. Water Research Commission, Pretoria, South Africa.

NEWTON AR, SHONE RW and BOOTH PWK (2006) The Cape Fold Belt. In: Johnson MR, Anhaeusser CR and Thomas R J (eds.) The Geology of South Africa. Geological Society of South Africa, Johannesburg/Council for Geoscience, Pretoria. 521-530.

ROBERTS DL, BOTHA GA, MAUD RR and PETHER J (2006) Coastal Cenozoic deposits. In: Johnson MR, Anhaeusser, CR and Thomas, RJ (eds.) The Geology of South Africa. Geological Society of South Africa, Johannesburg/Council for Geoscience, Pretoria. pp. 605-628.

SHARP JMA (1999) Glossary of Hydrogeological Terms. Department of Geological Sciences, The University of Texas.

THAMM AG and JOHNSON M R (2006) The Cape Supergroup. In: Johnson MR, Anhaeusser CR and Thomas RJ (eds.) The Geology of South Africa. Geological Society of South Africa, Johannesburg/ Council for Geoscience, Pretoria. 443-460.

THERON JN, GRESSE PG, SIEGFRIED HP and ROGERS J (1992) The Geology of the Cape Town area: Explanation of Sheet 3318 , scale 1:250 000. Geological Survey of South Africa, Department of Mineral and Energy Affairs, Pretoria.

XU Y, LIN L and JIA H (2009) Groundwater flow conceptualisation and storage determination of the Table Mountain Group (TMG) aquifers. WRC Report No. 1419/1/09. Water Research Commission, Pretoria, South Africa. 